\title{
Niemann-Pick disease type C: mutations of NPC1 gene and the course of disease
}

\author{
Ljerka Cvitanović-Šojat ${ }^{1}$, Maša Malenica ${ }^{1}$, Monika Kukuruzović ${ }^{1}$, Tamara Žigman ${ }^{1}$, \\ Kristina Kužnik'1, Ana Bielen²
}

\begin{abstract}
Niemann-Pick disease type C (NP-C) is a rare autosomal recessive disorder caused by mutations in the NPC1 gene in 95\% of cases. Consequently, unesterified cholesterol accumulates in late endosomes/lysosomes causing extremely varied neurovisceral symptoms. For many countries including Croatia, there are no reported NP-C cases to date, mainly because the accurate diagnosis of NP-C requires not easily accessible biochemical and molecular-genetic laboratory tests. Therefore, with the aim to improve clinical practice and understanding of NP-C in the region, we present the first siblings with NP-C recorded in Croatia. The diagnosis was based on histologic, biochemical and genetic tests. Namely, filipin staining showed accumulation of unesterified cholesterol and cultured skin fibroblasts were deficient in esterification of exogenously administered cholesterol. Electron microscopy of skin biopsy revealed the presence of sequestrated lipids in lysosomes. Molecular analyses showed both siblings to be compound heterozygotes for two disease-causing mutations of NPC1 protein, N1156S and Q922X. Based on comparison with previously reported N1156S homozygotes, we propose that Q922X mutation, causing the formation of a truncated NPC1, has a more severe impact on clinical outcome. Further, we observed pronounced differences in the disease course in the siblings; i.e. in the boy we observed an earlier onset and a much faster neurologic deterioration (late infantile onset), suggesting other genetic and/or environmental factors influencing the course of the disease. In contrast, the girl exhibited juvenile type of NP-C. In conclusion, when progressive neurologic symptoms develop in late childhood and with a previous history of neonatal cholestasis, the classic late infantile or juvenile type of NP-C must be suspected.
\end{abstract}

Keywords: Niemann-Pick Disease, type C; siblings; NPC1 protein, human

\section{INTRODUCTION}

Niemann-Pick disease type C (NP-C, OMIM 257220) is an autosomal recessive lysosomal lipid storage disorder with extremely heterogeneous clinical representation. NP-C is a rare panethnic disease with a minimal calculated incidence of 1:150 000 live births. It is caused by mutations in the NPC1 and/or NPC2 genes (1, 2). Approximately 95\% of NP-C cases have mutations in the NPC1 gene (MIM 607623; chromosome 18q11-q12), encoding a large glycoprotein (1278 amino acids) with 13 transmembrane domains that resides primarily in membrane of late endosomes (LE). The rest of patients have mutations in the NPC2 gene (MIM 601015; chromosome 14q24.3) encoding a soluble and glycosylated protein present in the LE lumen. In healthy individuals, NPC1 and NPC2 act together as a cellular duo that catalyzes mo- bilization of cholesterol and its export out of the LES (1-5). Consequently, mutations in one or both genes lead to accumulation of unesterified cholesterol and glycosphingolipids in late endosomes/lysosomes causing various neurovisceral symptoms $(1,6)$. Today, the NP-C disease variation

\footnotetext{
${ }^{1}$ Clinical Department of Pediatrics, Neurology Unit, Sestre milosrdnice University Hospital Center, Zagreb, Croatia ${ }^{2}$ Laboratory of Biology and Microbial Genetics,

Department of Biochemical Engineering, Faculty of Food Technology and Biotechnology, Zagreb, Croatia
}

\section{Correspondence to:}

Ljerka Cvitanović-Šojat, MD, PhD; Clinical Department of Pediatrics, Neurology Unit; Sestre milosrdnice University Hospital Center; Vinogradska cesta 29; 10000 Zagreb, Croatia; e-mail: ljerka-cvitanovic.sojat@zg.t-com.hr

Primljeno/Received: 18. 2. 2014., Prihvaćeno/Accepted: 15. 9. 2014. 
database lists 252 disease-causing sequence variants of the NPC1 gene and 18 of the NPC2 gene (November, 2013) (7). It has been shown that mutations correlate with neurologic forms of the disease, and nonsense and frameshift mutations are causing the most severe neurologic course (1). NPC has extremely heterogeneous clinical presentation, with a wide range of symptoms that are not specific for the disease. The age at onset also varies greatly with neonatal, early infantile (age at onset 2 months to 2 years), late infantile (2-6 years), juvenile (6-15 years) and adult ( $>15$ years) forms. Further, lifespan of patients can be from few days to over 60 years of age, with the majority of patients dying between 10 and 25 years of age. The major systemic symptoms include foetal ascites/hydrops, neonatal cholestasis and (hepato)splenomegaly. Neurologic symptoms are delay in motor milestones and hypotonia for early infantile form of the disease; gait problems, clumsiness, speech delay and cataplexy for late infantile form; school problems, ataxia, seizures and cataplexy for juvenile form; and psychiatric problems, ataxia, dystonia and dementia for adult form. Vertical supranuclear gaze palsy can also appear in all forms of the disease $(1,8,9)$. After NP-C has been suspected based on clinical symptoms, it is necessary to confirm the diagnosis by histologic, biochemical and genetic tests. Due to impaired intracellular cholesterol transport in NP-C, esterification of exogenously administered cholesterol by cultured skin fibroblasts is deficient at 4.5 or 6 hours. Furthermore, fluorescent filipin staining shows accumulation of unesterified cholesterol in lysosomes $(1,8)$. Electron microscopy (EM) of skin biopsy may reveal the presence of sequestrated lipids in lysosomes (10). Also, because of prenatal diagnosis or identifications of carriers in the family, it is advisable to do genetic testing $(1,8)$.

The accurate diagnosis of this rare disease is often a prolonged process, with a high probability of misdiagnosis due to heterogeneity and non-specificity of its clinical symptoms that arise and progress over varied periods of time (8, 11). Further, for many countries including Croatia, there are no reported NP-C cases to date. Therefore, the aim of this paper is to improve clinical practice and understanding of NP-C. As an illustration, we present the first cases of NP-C disease recorded in Croatia, with emphasis on the importance of early and accurate diagnosis for the patient and for the family.

\section{SUBJECTS AND METHODS}

Two siblings, a female born in 1987 and a male born in 1992, having juvenile and late infantile form of NP-C, respectively, were born after uneventful pregnancy and delivery. Birth parameters were normal (body weight, body length, head circumference, APGAR). Both had neonatal jaundice, hepatosplenomegaly and cholestasis that was resolved in a few months following birth. Developmental milestones were reached normally, until the onset of the disease.

The girl was 5 years old when hepatosplenomegaly was noticed and had lower interest, concentration and poor drawing abilities. At the age of seven years, before entering school, tests were performed and mild intellectual disability was shown (reduced school program). Dysrhythmic electroencephalogram (EEG) was recorded, while computed tomography (CT) of the brain and laboratory tests were still normal. At the age of nine, the aspartate transaminase (AST) level was at the upper limit of the reference range (47 $U / L)$, without hepatosplenomegaly and with normal other liver tests. She did not have a phenotype or laboratory signs of hypoplasia/atresia of bile ducts or cholestatic liver disease. Magnetic resonance (MR) of the brain showed periventricular demyelination, first in frontal and then in occipital region, but no cortical atrophy. Leukodystrophy of Pelizaeus-Merzbacher and white-matter disease were suspected. Neurologic symptoms developed, including clumsiness, dystonic/athetotic movements, dysmetria, ataxic/spastic gait, increased muscle tone and deep tendon reflexes, slurred, nasal and poor speech, supported walk, and paresis of upward gaze. She had dysrhythmic EEG; dyssynchrony of visual evoked potentials (VEP). Brain stem evoked response audiometry (BERA), electromyoneurography (EMNG), cerebrospinal fluid (CSF) and skin biopsy by EM were normal. Mitochondrial, peroxisomal and Wilson diseases were excluded based on laboratory testing. Catalytic activities of $\beta$ hexosaminidase $A$ and $A$ and $B(\beta H E X A A \& B), \beta$-galactosidase ( $\beta G A L), \beta$-glucosidase ( $\beta G L U C$ ) and arylsulfatase $A$ (ARILSA) were within the reference values. Grand mal seizure in duration of 5 minutes occurred at the age of 9 years and 9 months. Therapy with valproic acid, carbamazepine and phenobarbital was started. At the time, NP-C was suspected and the second skin biopsy revealed lipid inclusions in dermal axons leading to the diagnosis. The diagnosis of NP-C was confirmed in cultured fibroblasts by filipin test and very low esterification of exogenously administered cholesterol. Therapy included low cholesterol diet, lovastatin, cholestyramine and niacin. At the age of 10 years and 5 months, the clinical picture was progressively deteriorating, with brain MR showing not only demyelination but also cortical atrophy. Intractable epilepsy developed. Therapy with vigabatrin and neurontin was introduced, low cholesterol diet was stopped. When she was 11 years old, she was in vegetative state and percutaneous endoscopic gastrostomy (PEG) had to be applied with supportive measures and palliative care. She also had insomnia. She died when she was 11 years and 10 months old. Autopsy revealed bal- 


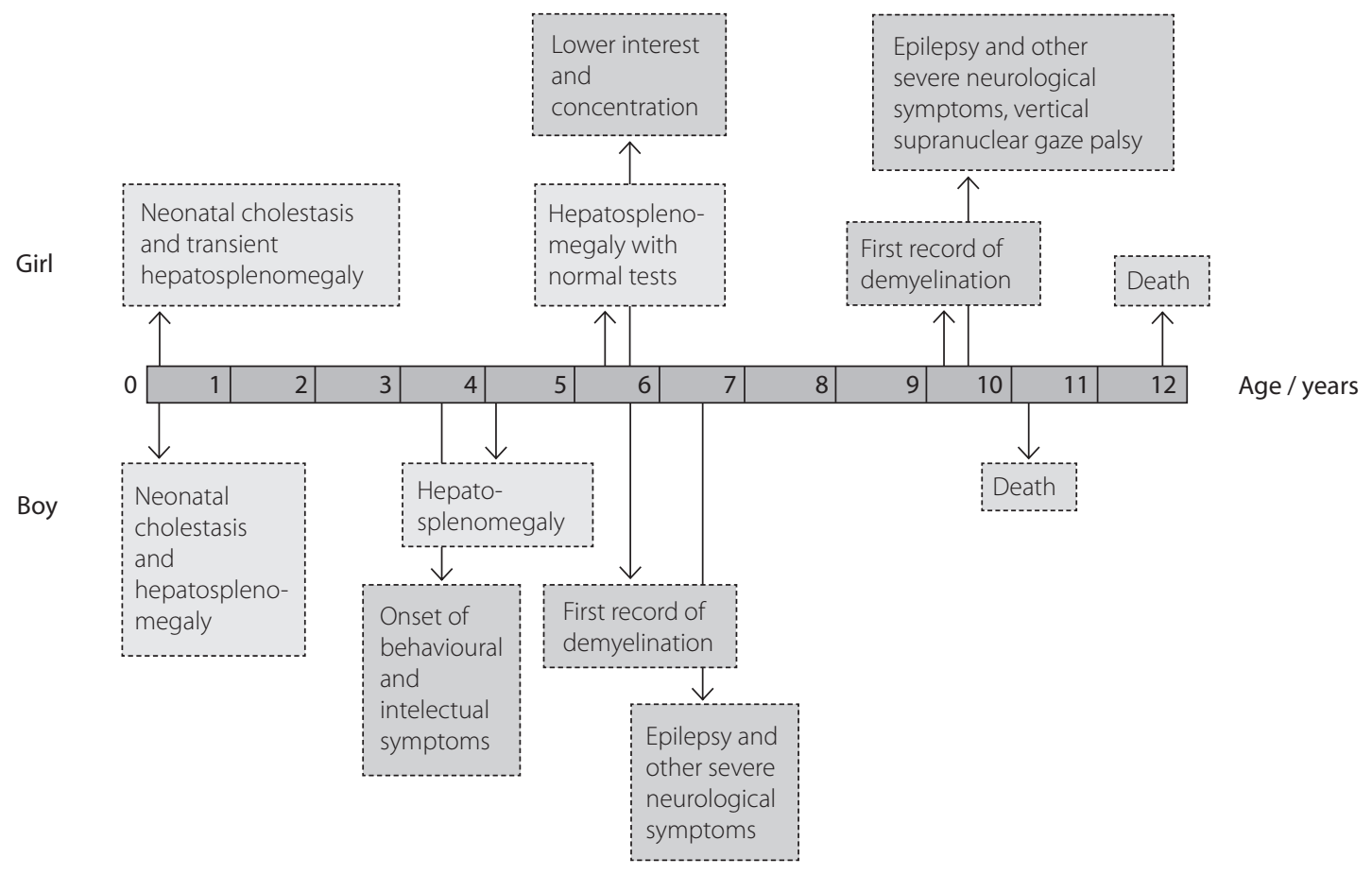

FIGURE 1. Timeline presentation of the Niemann-Pick disease type $C$ course in siblings

looning of neuronal cytoplasm and lipid laden foam cells in the spleen, liver, lymph nodes and bone marrow.

The male sibling had earlier onset and faster progress of the disease (Figure 1). At the time he was born, his elder sister had not yet been correctly diagnosed as NP-C. After birth, he had neonatal jaundice, hepatosplenomegaly and cholestasis that was resolved in a few months following birth. When the boy was 1.5 year old, he fell from 3-m height and sustained head trauma and leg fracture. In his early childhood, he suffered frequent viral infections. Despite normal early development, the first symptoms of NP-C appeared as very slow speech development (2-3 words at 3.5 years). At the age of 4 years, behavioral and cognitive problems appeared, such as hyperactivity, poor memory and slurred speech. Logotherapy was started. He had hepatosplenomegaly, AST $44 \mathrm{U} / \mathrm{L}$ and bile acid $10 \mathrm{mmol} / \mathrm{L}$. Other liver tests were normal and there were no phenotype/laboratory signs for hypoplasia/atresia of bile ducts and cholestatic liver disease. Skin biopsy was done when the boy was 5 years and 8 months old. In contrast to the results of his sister's skin biopsy, no lipid inclusions were found. Nevertheless, in fibroblasts filipin test was positive and exogenously administered cholesterol esterification defective, leading to the diagnosis of NP-C. Although EEG, VEP and laboratory tests were normal at the time, IQ was 86, and MR revealed demyelination in the occipital part of the brain. Therapy with lovastatin, cholestyramine, niacin and lowcholesterol diet was administered. At the age of 6 years, epilepsy fits started, EEG was dysrhythmic, dysarthria and ataxia appeared. He was enrolled in the school for children with special needs (mild intellectual disability). Carbamazepine and vigabatrin were added to therapy, while cholesterol-lowering therapy was stopped since there was no evidence for amelioration of neurologic symptoms. He died when he was 10 years and 3 months old.

Molecular analysis at first excluded the most prevalent NP-C causing 11061T mutation (12) (by courtesy of M.T. Vanier) and after the deaths it was found that both siblings were compound heterozygotes for two disease-causing mutations in the NPC1 gene (courtesy of S. Calandra). NPC1 allele with A3467G mutation in exon 22 codes for defective protein with the amino acid serine instead of asparagine at position 156 (N1156S), while C2764T in exon 18 causes nonsense mutation, i.e. conversion of the amino acid glutamine into a stop codon (Q922X). The probands' mother was heterozygous for Q922X mutation and probands' father was heterozygous for N1156S mutation.

\section{DISCUSSION AND CONCLUSIONS}

Niemann-Pick disease type $\mathrm{C}$ is a rare panethnic disease, but data on disease-causing mutations were collected mostly in Western Europe and the USA (7). This has led us to present the first case of siblings with NP-C in Croatia with the aim to improve clinical practice and understanding of NP-C in the region. 
Molecular analyses showed that both siblings were compound heterozygotes for two disease-causing mutations in the NPC 1 gene, leading to the production of defective NPC1 protein variants with N1156S and Q922X mutations. The N1156S mutation is positioned within the luminal portion of NPC1, between the $10^{\text {th }}$ and $11^{\text {th }}$ transmembrane domain. It seems that this allele has a considerably wide distribution because, besides the cases presented here, it has been found in several patients from Spain (13), United Kingdom (14), Israel (15) and elsewhere (16). Only the Israeli patient was homozygous and therefore offered an opportunity to study the effect of this particular mutation on the phenotype. This patient had juvenile onset of symptoms (hepatosplenomegaly at 4 months), but otherwise showed moderate clinical phenotype in comparison to our siblings. Therefore, we presume that in the case of siblings presented here, Q922X mutation (17), causing the formation of a truncated NPC 1 protein of 921 amino acids, had a more severe impact on the clinical outcome than N1156S mutation. Correlation of nonsense mutations of NPC1 and early neurologic onset and shorter life span was suggested earlier (18). Interestingly, this mutation was found only in genomic DNA, while in associated cDNA it was not detectable (data not shown). This raises the possibility of degradation of mRNA containing premature stop codon (17). In the analyzed family, direct consanguinity was not detected, but both parents trace their origin from the island of Krk: maternal grandparents have second cousins from the village of Linardići (Krk), while paternal grandfather is from Punat (Krk). It is well known that some villages on the island of Krk present small, isolated and highly inbred populations, therefore with a high chance of unusually high frequencies of otherwise rare genetic variants (e.g., hereditary dwarfism) (19).

Although both siblings were of the same NPC1 genotype, phenotypic differences could be observed (Figure 1). As described in more detail above, in the neonatal and early infantile period both siblings had transient jaundice and hepatosplenomegaly. In the girl, symptoms appeared on the $20^{\text {th }}$ day of life and lasted for 3 months, and the boy had symptoms from the birth, the symptoms were more pronounced and lasted for 6 months. Afterwards, both siblings had normal developmental milestones. At the age of 5 years, a loss of interest and concentration with poor drawing was noticed in the girl. In comparison, the boy exhibited behavioral problems, hyperactivity, poor memory and slurred speech at the age of 4 years. At the age of 7 years, the girl had dysrhythmic EEG, normal CT of the brain and because of borderline intellectual disability she was admitted to the regular school with reduced school program. The boy had 6.5 years of age, dysarthria and ataxia were observed, and he was admitted to the school for children with special needs because of mild intellectual disability. When the girl was 9 years old, there was no hepatosplenomegaly and there were no laboratory signs of hypoplasia or atresia of bile ducts or cholestatic liver disease. At the same time, gastroenterological examination performed in the boy at the age of 4 years showed mild hepatosplenomegaly, but no laboratory signs of liver disease. The girl learned to write and read, but at the age of 9 years and 4 months she stopped to go to school because of dystonia, athetosis, dysmetria, ataxia, spastic gait, slurred nasal and poor speech, and MR of the brain showed high signal in the periventricular occipital region. Extensive neuropediatric workup was done and results were normal including EM skin biopsy, only some changes were seen on EEG and VEP. Because of the progression of demyelination in the frontal and occipital part and because of the first grand mal attack at the age of 9 years and 9 months, paresis of upward gaze and deterioration of motor skills, skin biopsy was repeated and lipid inclusions in dermal axons were found suggesting the diagnosis of NP-C. The boy had his first epileptic fit at a younger age (6 years), the first MR of the brain at the age of 7 years showing demyelination in the occipital part; EEG, VEP and EM skin biopsy showed normal results. When the girl had 10 years and 5 months and the boy 5 years and 8 months, NP-C was confirmed by assaying cultured fibroblasts for cholesterol esterification and staining for unesterified cholesterol with filipin. At 10 years and 10 months, the girl had progression of demyelination with cortical atrophy, progressive deterioration with intractable epilepsy. At the age of 11 years, the girl was in vegetative state with insomnia, received PEG and died at 11 years and 10 months having permanent epileptic attacks despite antiepileptic polytherapy. The boy went to special school for two years and was not able to write and read. He had frequent epileptic attacks, dysarthria, ataxia, athetosis, spastic gait, slurred nasal and poor speech, followed by deterioration and death at the age of 10 years and 3 months. The parents had a third child, a healthy boy later diagnosed as heterozygous for the GIn922X mutation.

The studies of families with NP-C have shown that the affected siblings present a similar clinical course $(1,20)$. However, differences between siblings bearing the same alleles are also described, e.g., patients with the perinatal form can have siblings with infantile- or juvenile-onset neurologic disease $(9,14,21)$. As described here, in the boy we observed an earlier onset and a much faster neurologic deterioration (late infantile NP-C), suggesting other genetic and/ or environmental factors influencing the course of the disease. In contrast, the girl exhibited juvenile type of NP-C.

Due to the heterogeneous symptoms and age at onset, NP$C$ is often misdiagnosed $(8,11)$. Even when clinical tests exclude other diseases, confirmation of NP-C requires further 
biochemical and molecular-genetic laboratory tests. In the cases presented here, the diagnosis of NP-C in siblings was hampered by rarity of the disease leading to insufficient clinical awareness, as well as nonexistence of the required laboratory testing in Croatia. Therefore, with the extreme commitment of physicians and family, necessary tests were conducted in the University Medical Center, New York (skin biopsy for determination of lipid inclusions in dermal axons, E.H. Kolodny), Institut National de la Santé et de la Recherche Médicale, Lyon (filipin test and cholesterol esterification in fibroblasts, M.T. Vanier) and Dipartimento di Scienze Biomediche, Metaboliche e Neuroscienze Modena (molecular genetic analyses, S. Calandra). It has to be noted that both biochemical tests in fibroblasts are necessary for accurate NP-C diagnosis, since reliance on one or the other may lead to the diagnosis being missed in some cases: the transport of cholesterol is studied by cholesterol esterification studies and the storage of cholesterol is assessed by staining the cells with filipin, which glows under ultraviolet light $(8,21)$. Skin biopsy of dermal axons was positive for lipid inclusions only in the female sibling. Therefore, this test has to be taken with caution. The diagnosis should be confirmed in suspected cases by genetic testing (i.e. DNA sequencing) (9).

At the time of the study, there was no disease-modifying therapy available for NP-C (8). Therefore, therapy was limited to supportive measures, including pharmacotherapy to alleviate neurologic symptoms, such as antiepileptic drugs. At the time, a combination of hypocholesterolemic drugs and low-cholesterol diet was suggested to alleviate the symptoms, but no amelioration of the neurologic disease was observed in the presented case, or in the literature (22). It was recently shown that miglustat ( $\mathrm{N}$-butyldeoxynojirimycin; NB-DNJ; Zavesca® ${ }^{\oplus}$, Actelion Pharmaceuticals Ltd.) delays the onset of neurologic symptoms. This molecule acts as an inhibitor of glucosylceramide synthase, which glucosylates ceramide to form glucosylceramide, the first step in the synthesis of glycosphingolipids (9). Miglustat has the ability to cross the blood-brain barrier and to prolong survival in animal models of NP-C $(23,24)$. Today, the European Union has extended the indication of miglustat to the treatment of progressive neurologic manifestations in adult and paediatric patients with NP-C, and the drug is now approved for this indication in several other countries as the first specific treatment for NP-C that can slow down or stop the progression of neurologic symptoms $(1,8,9)$. The approval of miglustat was based on data from several studies that showed stabilization of the neurologic disease course in patients treated for one year or more (25-28). Regarding the cases presented here, the female sibling did not receive miglustat because at the time it was still under investigation and she was deteriorated and in vegetative state. Following insuffi- cient information about the pharmacokinetics, efficacy and safety in NP-C patients, the male sibling did not enter clinical trial in 2000.

In conclusion, in late childhood when progressive neurologic symptoms develop and with a previous history of neonatal cholestasis without known aetiology, a classic late infantile or juvenile type of NP-C must be suspected. A timely and accurate diagnosis is important because now it allows not only support and palliative care but also early miglustat therapy, as well as appropriate family counselling.

\section{ACKNOWLEDGMENTS}

The authors would like to thank M.T. Vanier, S. Calandra, E. Kolodny, P.G. Penchev, M.C. Patterson, J.E. Wraith, J. Imrie, B. Bambi, The Ara Parseghian Medical Research Foundation and Niemann Pick Disease Group UK for help with cytologic, biochemical and molecular biology testing of the patients and parents and for the support.

\section{Abbreviations:}

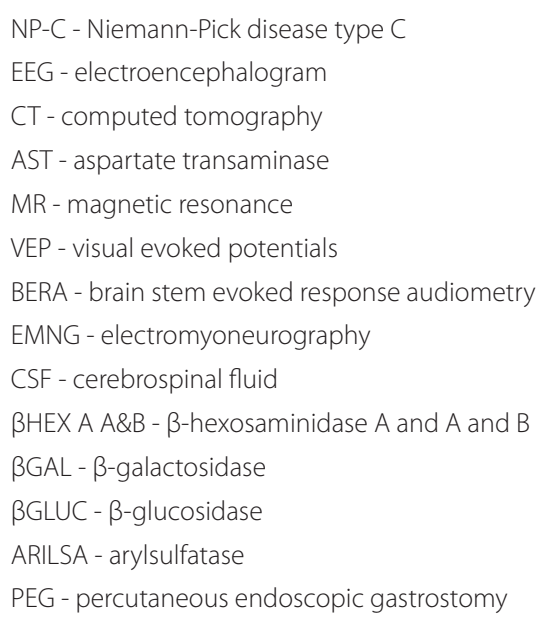

\section{NOVČANA POTPORA/FUNDING}

Nema/None

\section{ETIČKO ODOBRENJE/ETHICAL APPROVAL}

Nije potrebno/None

\section{DOPRINOSI AUTORA/DECLARATION OF AUTHORSHIP}

Svi autori jednako su doprinijeli izradi rada/All authors have equally contributed to a manuscript writing

\section{SUKOB INTERESA/CONFLICT OF INTEREST}

Autori su popunili the Unified Competing Interest form na www.icmje.org/ coi_disclosure.pdf (dostupno na zahtjev) obrazac i izjavljuju: nemaju potporu niti jedne organizacije za objavljeni rad; nemaju financijsku potporu niti jedne organizacije koja bi mogla imati interes za objavu ovog rada u posljednje 3 godine; nemaju drugih veza ili aktivnosti koje bi mogle utjecati na objavljeni rad./All authors have completed the Unified Competing Interest form at www.icmje.org/coi_disclosure.pdf (available on request from the corresponding author) and declare: no support from any organization for the submitted work; no financial relationships with any organizations that might have 
an interest in the submitted work in the previous 3 years; no other relationships or activities that could appear to have influenced the submitted work.

\section{REFERENCES}

1. Vanier M. Niemann-Pick disease type C. Orphanet J Rare Dis. 2010;5:1-18 http://dx.doi.org/10.1186/1750-1172-5-16

2. Vanier MT, Millat G. Niemann-Pick disease type C. Clin Genet. 2003;64:269-81. http://dx.doi.org/10.1034/j.1399-0004.2003.00147.x

3. Infante RE, Wang ML, Radhakrishnan A, Kwon HJ, Brown MS, Goldstein JL. NPC2 facilitates bidirectional transfer of cholesterol between NPC1 and lipid bilayers, a step in cholesterol egress from lysosomes. Proc Natl Acad Sci U S A. 2008;105:15287-92. http://dx.doi.org/10.1073/pnas.0807328105

4. Subramanian K, Balch WE. NPC1/NPC2 function as a tag team duo to mobilize cholesterol. Proc Natl Acad Sci U S A. 2008;105:15223-4. http://dx.doi.org/10.1073/pnas.0808256105

5. Sleat DE, Wiseman JA, El-Banna M et al. Genetic evidence for nonredundant functional cooperativity between NPC1 and NPC2 in lipid transport. Proc Natl Acad Sci U S A. 2004;101:5886-91. http://dx.doi.org/10.1073/pnas.0308456101

6. Rosenbaum Al, Maxfield FR. Niemann-Pick type C disease: molecular mechanisms and potential therapeutic approaches. J Neurochem. 2011;116:789-95. http://dx.doi.org/10.1111/j.1471-4159.2010.06976.x

7. Runz H, Dolle D, Schlitter AM, Zschocke J. NPC-db, a Niemann-Pick type C disease gene variation database. Hum Mutat. 2008;29:345-50. http://dx.doi.org/10.1002/humu.20636

8. Wraith JE, Baumgartner MR, Bembi B et al. Recommendations on the diagnosis and management of Niemann-Pick disease type C. Mol Genet Metab. 2009;98:152-65. http://dx.doi.org/10.1016/j.ymgme.2009.06.008

9. Patterson MC, Hendriksz CJ, Walterfang M, Sedel F, Vanier MT, Wijburg F. Recommendations for the diagnosis and management of Niemann-Pick disease type C: An update. Mol Genet Metab. 2012;106:330-44. http://dx.doi.org/10.1016/j.ymgme.2012.03.012

10. Boustany RMN, Kaye E, Alroy J. Ultrastructural findings in skin from patients with Niemann-Pick disease, type C. Pediatr Neurol. 1990;6:177-83. http://dx.doi.org/10.1016/0887-8994(90)90059-A

11. Lo SM, McNamara J, Seashore MR, Mistry PK. Misdiagnosis of Niemann-Pick disease type $C$ as Gaucher disease. J Inherit Metab Dis. 2010;33 (Suppl 3):429-33.

http://dx.doi.org/10.1007/s10545-010-9214-3

12. Park WD, O'Brien JF, Lundquist PA et al. Identification of 58 novel mutations in Niemann-Pick disease type C: Correlation with biochemical phenotype and importance of PTC1-like domains in NPC1. Hum Mutat. 2003;22:313-25. http://dx.doi.org/10.1002/humu.10255

13. Fernandez-Valero EM, Ballart A, Iturriaga $C$ et al. Identification of 25 new mutations in 40 unrelated Spanish Niemann-Pick type $C$ patients: genotype-phenotype correlations. Clin Genet. 2005;68:245-54. http://dx.doi.org/10.1111/j.1399-0004.2005.00490.x

14. Imrie J, Dasgupta S, Besley GT et al. The natural history of Niemann-Pick disease type $C$ in the UK. J Inherit Metab Dis. 2007;30:51-9. http://dx.doi.org/10.1007/s10545-006-0384-7
15. Meiner V, Shpitzen S, Mandel H et al. Clinical-biochemical correlation in molecularly characterized patients with Niemann-Pick type C. Genet Med. 2001;3:343-8 http://dx.doi.org/10.1097/00125817-200109000-00003

16. Sun X, Marks DL, Park WD et al. Niemann-Pick C variant detection by altered sphingolipid trafficking and correlation with mutations within a specific domain of NPC1. Am J Hum Genet. 2001;68:1361-72. http://dx.doi.org/10.1086/320599

17. Tarugi P, Ballarini G, Bembi B et al. Niemann-Pick type C disease. J Lipid Res. 2002;43:1908-19. http://dx.doi.org/10.1194/jlr.M200203-JLR200

18. Millat $G$, Marçais $C$, Tomasetto $C$ et al. Niemann-Pick C1 disease: Correlations between NPC1 mutations, levels of NPC1 protein, and phenotypes emphasize the functional significance of the putative sterolsensing domain and of the cysteine-rich luminal loop. Am J Hum Genet. 2001;68:1373-85. http://dx.doi.org/10.1086/320606

19. Krzisnik C, Kolacio Z, Battelino T, Brown M, Parks JS, Laron Z. The "Little People" of the island of Krk-revisited. Etiology of hypopituitarism revealed. Int J Disabil Hum Dev. 1999;1:9-20. http://dx.doi.org/10.1515/IJDHD.1999.1.1.9

20. Yatziv S, Gershon Z, Ornoy A, Bach G. Clinical heterogeneity in a sibship with Niemann-Pick disease type C. Clin Genet. 1983;23:125-31. http://dx.doi.org/10.1111/j.1399-0004.1983.tb01860.x

21. Vanier MT, Wenger DA, Comly ME, Rousson R, Brady RO, Pentchev PG. Niemann-Pick disease group C: clinical variability and diagnosis based on defective cholesterol esterification: A collaborative study on 70 patients. Clin Genet. 1988;33:331-48. http://dx.doi.org/10.1111/j.1399-0004.1988.tb03460.x

22. Schiffmann R. Niemann-Pick disease type C. JAMA. 1996;276:561-4. http://dx.doi.org/10.1001/jama.1996.03540070057031

23. Treiber A, Morand O, Clozel M. The pharmacokinetics and tissue distribution of the glucosylceramide synthase inhibitor miglustat in the rat. Xenobiotica. 2007;37:298-314. http://dx.doi.org/10.1080/00498250601094543

24. Zervas M, Somers KL, Thrall MA, Walkley SU. Critical role for glycosphingolipids in Niemann-Pick disease type C. Curr Biol. 2001;11:1283-7. http://dx.doi.org/10.1016/S0960-9822(01)00396-7

25. Patterson MC, Vecchio D, Jacklin E et al. Long-term miglustat therapy in children with Niemann-Pick disease type C. J Child Neurol. 2010;25:300-5. http://dx.doi.org/10.1177/0883073809344222

26. Patterson MC, Vecchio D, Prady H, Abel L, Wraith JE. Miglustat for treatment of Niemann-Pick $C$ disease: a randomised controlled study. Lancet Neurol. 2007;6:765-72. http://dx.doi.org/10.1016/S1474-4422(07)70194-1

27. Pineda $M$, Wraith J, Mengel E et al. Miglustat in patients with Niemann-Pick disease Type C (NP-C): a multicenter observational retrospective cohort study. Mol Genet Metab. 2009;98:243-9. http://dx.doi.org/10.1016/j.ymgme.2009.07.003

28. Wraith JE, Vecchio $D$, Jacklin $E$ et al. Miglustat in adult and juvenile patients with Niemann-Pick disease type C: long-term data from a clinical trial. Mol Genet Metab. 2010;99:351-7. http://dx.doi.org/10.1016/j.ymgme.2009.12.006 


\title{
SAŽETAK
}

\section{Niemann-Pickova bolest tip C: mutacije gena NPC1 i tijek bolesti}

\author{
Lj. Cvitanović-Šojat, M. Malenica, M. Kukuruzović, T. Žigman, K. Kužnik, A. Bielen
}

\begin{abstract}
Niemann-Pickova bolest tip C rijedak je autosomni recesivni poremećaj, u 95\% slučajeva uzrokovan mutacijama gena NPC1. Kao posljedica mutacija dolazi do nakupljanja neesterificiranog kolesterola u kasnim endosomima/lizosomima, što uzrokuje vrlo raznolike neurovisceralne simptome. U mnogim zemljama, uključujući Hrvatsku, do danas nema opisanih slučajeva ove bolesti, uglavnom zbog toga što su za postavljanje točne dijagnoze potrebne teško dostupne biokemijske i molekularno-biološke laboratorijske pretrage. Stoga radi poboljšanja kliničke prakse i razumijevanja ove bolesti u regiji, opisujemo prvi slučaj brata i sestre oboljelih od NP-C-a za Hrvatsku. Dijagnoza se temeljila na histološkim, biokemijskim i genetičkim pretragama. Nakupljanje neesterificiranog kolesterola dokazano je "Filipin" bojenjem, a nedostatna esterifikacija izvana unijetog kolesterola dokazana je u kulturi fibroblasta. Elektronskom mikroskopijom biopsije kože dokazane su nakupine lipida u lizosomima. Molekularna analiza je pokazala da su brat i sestra heterozigoti, nositelji dviju mutacija gena NPC1, te je predvideno da proteini NPC1 nose mutacije N1156S i Q922X. Temeljem usporedbe s podatcima iz literature o N1156S homozigotima, pretpostavljeno je da je mutacija Q922X, koja uzrokuje preuranjeni završetak translacije proteina NPC1, značajnije utječu na kliničku sliku. Uz to su razlike u tijeku bolesti kod dječaka i djevojčice bile vrlo izražene. Kod dječaka su se prvi simptomi pojavili mnogo ranije i došlo je do bržeg neurološkog propadanja (kasni infantilni tip bolesti), vjerojatno zbog utjecaja drugih genetskih i/ili okolišnih čimbenika na tijek bolesti. Nasuprot tome, djevojčica je imala juvenilni tip bolesti. Zaključno, ako se nakon zabilježene neonatalne kolestaze u kasnom djetinjstvu pojave progresivni neurološki simptomi, treba posumnjati na klasični kasni infantilni ili juvenilni tip NP-C-a.
\end{abstract}

Ključne riječi: Niemann-Pickova bolest, tip C; blizanci; NPC1 protein, humani 